\title{
O Professor Waldemar Ferreira homenagea- do pela Universidade do Rio Grande do Sul
}

Em Assembléia Universitária realizada aos 3 de março de 1960, no Salão de Atos da Universidade do Rio Grande do Sul, em Pôrto Alegre, seu Magnífico Reitor, o Professor Elyseu Paglioli, procedeu à leitura do relatório das atividades da instituição no ano de 1959; e, em sintonia com as aspirações das Congregações de Professôres das Faculdades de Filosofia, de Direito e de Medicina de Pôrto Alegre, outorgou os títulos de professôres "honoris causa" aos Doutores Emílio Betti e Waldemar Ferreira, proferindo às seguintes palavras:

"Mas, senhores, a Universidade não distingue apenas os beneméritos egressos de seus quadros. Reserva, ao mesmo passo, um laurel a professôres eminentes que tenham exercido efetivamente o magistério em instituição de ensino superior de renome, com alto mérito para a ciência que professam, qual seja o título de "Professor Honoris Causa".

"Das mais felizes foi a iniciativa da ilustre Congregação da Faculdade de Direito de Pôrto Alegre, propondo ao Egrégio Conselho Universitário a outorga dêsse título aos professôres Waldemar Martins Ferreira, ex-professor catedrático da Faculdade de Direito de São Paulo, jurista e profissional de larga projeção, autor de obras jurídicas que lhe grangearam o título de "o maior de nossos comercialistas"; e a Emilio Betti, laureado em direito e letras, professor em quase tôdas as Universidades italianas, cultor de direito em suas mais variadas especializações, autor de copiosa e excelente bibliografia, que concorreu para firmar o seu nome entre o dos maiores juristas contemporâneos. 
Tanto Emilio Betti, como Waldemar Martins Ferreira, que, em distintas oportunidades, honraram esta instituição, professando magistrais lições de seu saber, são duas glórias autênticas das letras jurídicas".

Passou o Magnífico Reitor, logo depois, às mãos do Professor Waldemar Ferreira, que assinou o têrmo da concessão do título, com que foi honrado, expresso, em latim, no respectivo pergaminho, o original da portaria seguińte:

"O Reitor da Universidade do Rio Grande do Sul, no uso das atribuições que lhe confere o Estatuto, tendo em vista a proposição da Congregação da Faculdade de Direit̄o de Pôrt’ Allegre, e em execução da delibereçãc unànime do Conselho Universitário, em sessão de 13 de novembro de 1959, após aprovação também unânime, das Congregações dos Institutos que constituem esta Universidade;

considerando que o professor Waldemar Martins Ferreira, catedrático de Direito Comercial da Faculdade de Direito da Universidade de São Paulo, é amplamente conhecido nos meios universitários brasileiros, já por sua longa e brilhante carreira magisterial, já por suas inúmeras obras jurídicas;

considerando sua atuação de relêvo por ocasião do Congresso Jurídico realizado nesta Capital em comemoração ao cinqüentenário da Faculdade de Direito desta Universidade;

considerando que em diversas oportunidades tem, igualmente, o emérito jurista cooperado conosco, ora realizando conferências, ora cursos de extensão universitária;

considerando, finalmente, a sua imensa obra de doutrinação e ensino e o muito que lhe deve a ciência jurídica e, notadamente, a Faculdade de Direito de Pôrto Alegre, desta Universidade, por êle tantas vêzes distinguida, resolve outorgar ao professor Waldemar Martins Ferreira o titulo de "Professor honoris causa", pela Universidade do Rio Grande do Sul".

(a) Elysed Pagliol. Re Reitor." 